Please use the following citation where a final version of this paper can be found: Baig, M.B., Burgess, P.J., Fike J.H. (2020). Agroforestry for Healthy Ecosystems: Constraints, Improvement Strategies and Extension in Pakistan. Agroforestry Systems. https://doi.org/10.1007/s10457019-00467-4

\title{
Agroforestry for Healthy Ecosystems: Constraints, Improvement Strategies and Extension in Pakistan
}

Mirza B. Baig ${ }^{1}$, Paul J. Burgess², John H. Fike ${ }^{3}$

${ }^{1}$ Department of Agricultural Extension and Rural Society, College of Food and Agriculture Sciences, King Saud University, Riyadh 11451, Kingdom of Saudi Arabia e-mail: mbbaig@ksu.edu.sa

${ }^{2}$ Cranfield Soil and Agrifood Institute, School of Water, Energy and Environment, Cranfield University, Cranfield, Bedfordshire MK43 OAL, UK e-mail: P.Burgess@cranfield.ac.uk

${ }^{3}$ School of Plant and Environmental Sciences, Virginia Polytechnic Institute and State University (Virginia Tech), Blacksburg, VA 24061, USA e-mail: jfike@vt.edu

\section{ABSTRACT}

Globally, forest ecosystems are shrinking and their health is declining due to a range of biotic and abiotic factors. Forest ecosystems in Pakistan are no exception and the country faces a crisis as its growing population (> 208 million) places increasing pressure on the country's food production systems and forest resources. Effective food systems that enhance productivity, increase economic outputs, improve ecological outcomes and maintain social acceptance are needed. Agroforestry, a traditional land management system in Pakistan, offers the opportunity to meet these goals. Planting trees on private farmland provides clear ownership of any timber resource and well managed systems have great potential both to boost agriculture and reduce wood shortages. Concerted extension efforts have been made to introduce and promote innovative agroforestry practices in Pakistan, but the success of these efforts depends on many factors. This paper reviews some of the current constraints to agroforestry promotion in Pakistan, including attitudes of the extension staff, poor or weak research-extension coordination, lack of trained personnel, lack of farmer response to advice, tree species limitations, and market mechanism as well as wood price challenges. Establishing model agroforestry farms at the village level can be a productive extension approach, but successful extension programming requires partners to share both an appreciation of the problem and a vision of successful outcomes. Successful promotion also requires appropriate choice of message, messenger, target audience and effective use of appropriate communication tools. Remedial measures to streamline the existing systems and devise future sustainable strategies and approaches are suggested to promote agroforestry in Pakistan.

Keywords: Forestry, Tragedy of the commons, Alley cropping, Silvoarable, Technology transfer 


\section{INTRODUCTION}

Pakistan is primarily a farming society with $64 \%$ of its 208 million inhabitants living in rural areas, and $50 \%$ engaged in agriculture (Pakistan Economic Survey 2018). The country is facing an acute shortage of fuel, fodder and fiber. An estimated $80-90 \%$ of the rural population uses wood as its primary source of domestic energy, typically collecting this resource from common property and state-controlled forests or from agroforestry systems. A piece of land owned by the state located outside of almost every village, covered by only trees and grasses, is available to the village residents and is a form of agroforestry. These common property lands called "Shamlat" are supervised by the village head (Numberdar). The villagers typically enjoy equal rights to use them and to meet their domestic needs, collect dead branches as woodfuel and graze their animals. This simple form of agroforestry can provide locals and farmers fuel and feed and other products if such lands are not overused. However, still Pakistan needs to devise and implement effective land use practices for farmers' fields that can profitably produce food and fiber, enhance the environment and be socially viable. With appropriate management, agroforestry-the intentional integration of woody perennials with crops and/or livestock (FAO 2015b; Burgess and Rosati 2018) - can both increase farm production and enhance natural resources. This review outlines and discusses extension strategies to promote agroforestry in Pakistan, starting with a brief review of the current status of land use and agroforestry in the country. It then identifies some of the current constraints to agroforestry and provides information on successful examples of extension. The article also highlights strategies for improving agroforestry extension and, based on the discussion, conclusions are drawn to guide future plans.

The review was completed using databases available at the King Saud University, Saudi Arabia. Multitude sources-primarily peer-reviewed journals and "grey literature", but also publications of the government and the reports of foreign donors-were researched for this review. With the help of selected key words, we fully searched ISI Web of Knowledge and Google Scholar for information relevant to our topic. Key words and phrase searches included deforestation, degradation, forests, trees, agroforestry/farm forestry/social forestry/community forestry, landscapes, ecosystem, biodiversity, livelihoods, local/folk people, forest policy, and forest management.

\section{AGROECOLOGICAL ZONES OF PAKISTAN}

Pakistan covers an area of 87.98 million ha (Mha) situated between $23^{\circ}$ and $37^{\circ}$ north latitude and $61^{\circ}$ and $76^{\circ}$ east longitude. The country is divided into ten main agro-climatic zones (Fig. 1). Mountains cover more than two-thirds of the country on the northern and western boundaries, the Indus plains (I and II) extend over an area of about 20.7 Mha, and the Thar Desert (IIIb), a vast region of sand ridges, covers about 6.5 Mha. 


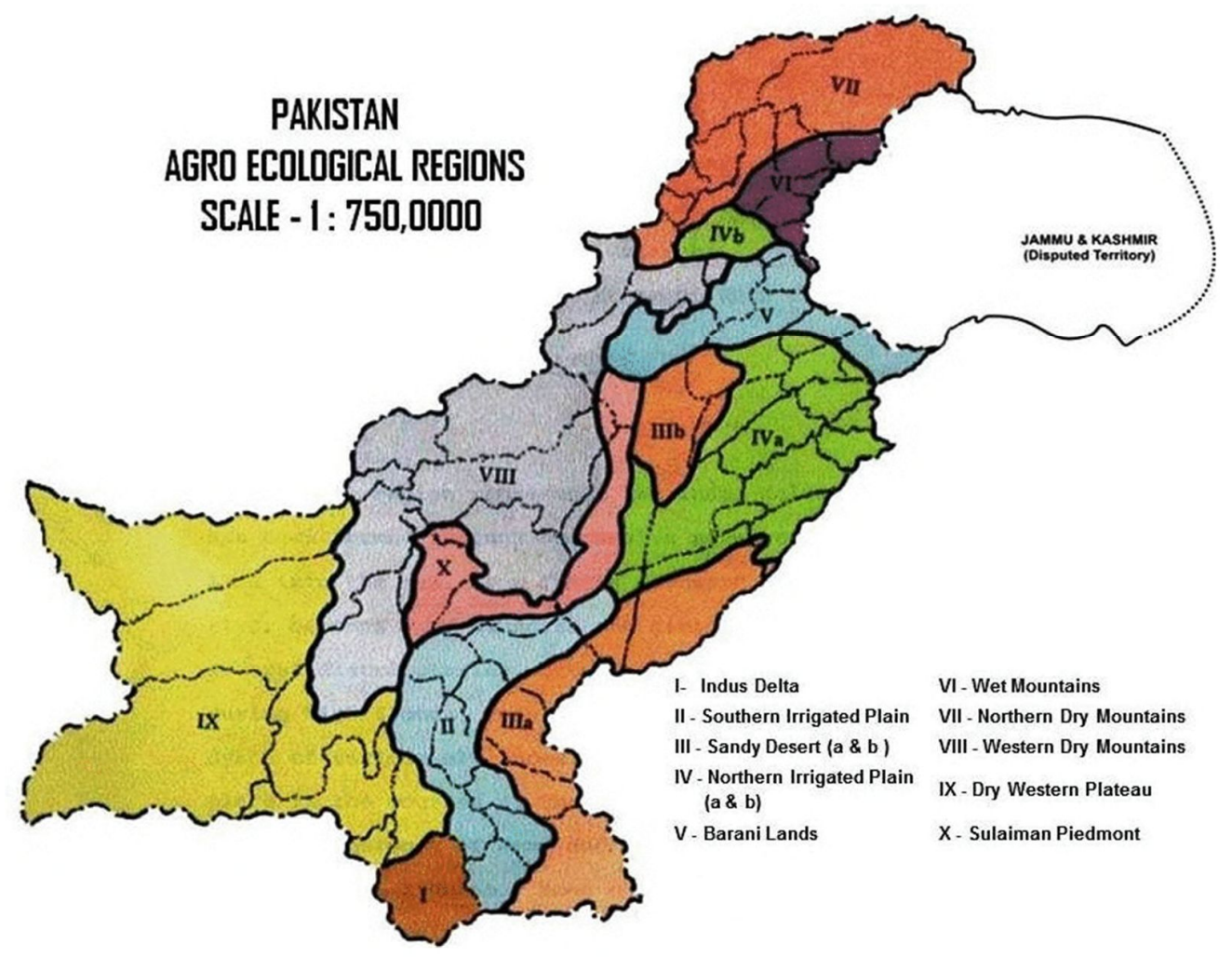

Fig. 1. Agro-ecological regions in Pakistan (Source: PARC, 2019)

The climate is generally arid subtropical, but intensively modified by altitude. The annual rainfall ranges from $125 \mathrm{~mm}$ in the extreme southern plains to between 500 and $875 \mathrm{~mm}$ in the country's mountainous and northern plains regions. About $70 \%$ of the total precipitation occurs as heavy storms between July and September. Summer months in the Indus plains and the Thar Desert are very hot with monthly mean maximum temperatures exceeding $40^{\circ} \mathrm{C}$, with temperature reaching up to $53^{\circ} \mathrm{C}$ on individual days. By contrast, in winter months, mean monthly temperature in the plains can be as low as 2 to $5^{\circ} \mathrm{C}$, while temperatures often fall below zero in mountainous areas.

Agroecosystems in Pakistan are straining under increasing demands for food and forest resources. Currently Pakistan is the world's sixth most populated country with mean population density of about 2.6 persons per ha (Pakistan Economic Survey 2018). The country's population increased from 32.5 million at the time of independence in 1947, to 208 million by 2017 (PBS 2017; Pakistan Economic Survey 2018), equivalent to an average growth rate of $2.7 \%$ per annum. With such growth rates, the country will have to double its annual food production every 15 years (Ali et al. 2017), but this is challenged by its limited resources. Within the total land area of 87.98 million hectares (Mha), just over 20 Mha are cultivated and 15.6 Mha are irrigated (Ministry of Finance 2007). Of the cultivated area, about $21 \%$ is double-cropped and $25 \%$ of the cultivated 
area remains fallow at any time. More than $80 \%$ of the arable land is irrigated which produces more than $90 \%$ of the total food for human consumption and feed for livestock (GOP 2008). However, due to competition among the farming communities for irrigation water supplies and climate change, huge water losses in water transportation through the canals means that water available at the farm gate decreases everyday (Ma et al. 2008; Ali et al. 2017).

As with agriculture, forest resources face critical challenges. Forest cover comprises 2.99 Mha or 3.9\% of the land area (FAO 2015a); thus, Pakistan ranks 110th among 195 countries in terms of the proportion of forested land area (Chaudhry 2011). The Government of Pakistan (GOP) (2013) recognizes the management of state-owned, communal, and privately owned forests must be improved to sustain adequate domestic supply of wood and wood products. Commercial forestry is practiced on $32.8 \%$ of the forest area, with the remaining two-thirds protected because of its important role in soil conservation, watershed protection and climatic functions. The trees on 29 million ha of rangelands and the 330 million trees on 19.3 million ha of farmlands contribute greatly to meeting the woodfuel demand in Pakistan (RWEDP 2000).

\section{SOCIO-ECONOMIC STATUS OF PAKISTAN}

About $64 \%$ of Pakistan's population live in rural areas and over $50 \%$ are engaged in agriculture. Agriculture accounts for $18.9 \%$ of the GDP and $\mathbf{4 2 . 3 \%}$ of total employment (Pakistan Economic Survey 2018). Therefore, a successful agriculture policy is critical to national economic growth and poverty reduction (Ministry of Finance 2007). The average household in rural areas is composed of six residents, with two earners per household (PBS 2016; Population Census 2017; Farooq et al. 2018), and thus a dependency ratio of 3:1. In addition, household incomes are much lower in rural areas than in urban areas. Although poverty is declining, $24.3 \%$ of people of Pakistan still live below the poverty threshold (World Bank 2018a, b, c). Country-wide literacy rates are about $62 \%$, with male literacy $(72.5 \%)$ substantially greater than for females $(51.8 \%)$ (Pakistan Economic Survey 2018-19).

The socio-economic arrangement of rural Pakistani villages can be categorized into three broad patterns based on ownership and control (Baig et al. 1999). In some cases, a single family owns the entire village, thereby controlling the whole local economy. In other cases, more than one family owns and rules the community but the situation of control in these villages is similar to that of single-family control. In the third situation, several small landowners own the village and they work together and with tenants to provide food and shelter (Baig et al.1999). About $80 \%$ of Pakistan's rural population consists of smallholders or landless people (Pakistan Economic Survey 2013; Shahbaz and Ata 2014). These people typically suffer from poverty, malnutrition, disease and ignorance and have no economic security. Their main occupation is agriculture which, in most cases, is carried out with primitive techniques. Most rural areas contain no largescale industries and the few craft and cottage industries that exist depend on the availability of raw material (Baig et al. 1999). Most goods and commodities consumed by the villages are 
produced within the villages themselves. Among village artisans are carpenters and blacksmiths who can construct and repair agricultural implements and tools. Historically, such artisans were paid in-kind with crops at harvest time but this has declined as skilled professionals have migrated to urban areas and factories now specialize in manufacturing agricultural tools and implements (Baig and Ehrenreich 1997; Baig et al. 1999).

\section{AGROFORESTRY IN PAKISTAN}

Agroforestry practices include land use systems that deliberately integrate trees or shrubs with agricultural crops and livestock in the same land management system (Nair 1993). Well-managed agroforestry systems can maximize production in a given space and time, whilst providing benefits such as soil stabilization and wildlife habitat. These practices are not new to Pakistan whose people traditionally grow trees in their home courtyards and on their land for multiple purposes. Historically, farmers often retained trees on their farms to sustain agricultural production, reduce soil erosion, retain water and provide shade, and generate income. Most commonly trees found on the farmlands in the Province of Punjab (Farooq et al. 2018) are presented in Table 1.

Table 1 Local and scientific names of trees commonly found on farmlands in the Province of Punjab (Source: Farooq et al. 2018)

\begin{tabular}{llll}
\hline Local name & Scientific name & Local name & Scientific name \\
\hline Shisham & Dalbergia sissoo & Beri & Ziziphus mauritiana \\
Kikar & Acacia nilotica & Neem & Azadirachta indica \\
Bakain & Melia azedarach & Bohar & Ficus benghalensis \\
Shatoot & Morus alba & Amrood & Psidium guajava \\
Poplar & Populus deltoides & Malta & Citrus sinensis \\
Sumbal & Bombax ceiba & Mango & Mangifera indica \\
Sufaidah & Eucalyptus camaldulensis & Jaman & Syzygium cumini \\
\hline
\end{tabular}

In recent decades, greater attention and importance have been given to these systems following the implementation of donor-funded projects and growing awareness of the benefits from such systems driven by governmental institutions. Conceptual and practical descriptions of agroforestry in Pakistan were provided as early as 1944 by Garland (1944), who worked in Sindh province. In 1985, Pakistan launched the "Forestry Planning and Development Project", its first nationwide social/agroforestry effort (Dove 1992). Later research showed that intercropping and integrating livestock could minimize the effects of crop failure in semi-arid areas of the country (Mohammad and Salim, 1989).

However, agroforestry implementation is not limited to marginal or degraded lands. On the homesteads and farmlands, trees have been planted as woodlots, in groups within fields, individually within pastures, or in shelterbelt rows along field boundaries; and these systems 
utilize a range of tree species. Sindh Province (Fig. 2) sustains the forests on huge areas; however, farmers raise trees in clumps to sale the poles and reclaim the degraded lands. In lower Sindh, farmers plant Acacia nilotica (Babul) as woodlots, locally called 'hurries'. Most of the natural forests of the country are found in the Khyber Pakhtunkhwa (KPK) Province, situated in the northern part of the country. Higher elevations of the KPK Province produce high quality fruit trees (Table 2) and are incorporated into farming systems. Populus spp. have also been planted on a mass-scale in the Province. Eucalyptus species cover vast areas in the Mastung Valley of Balochistan Province to enhance the vegetation cover, and generate income and woodfuel supplies (Fig. 2). The Punjab Province is known as the 'food and fruit basket' for the whole country, sustaining various irrigated, dry, rainfed and desert areas and producing different types of crops and trees. It has a very high potential of supporting various forms of agroforestry systems.

Table 2 Common fruit trees grown in Swat valley of KPK Province (decreasing order) (Jamilu et al. 2014)

\begin{tabular}{lll}
\hline Season & English name & Scientific name \\
\hline Winter fruits & Pear & Pyrus sp. \\
& Apple & Eriobotrya japonica \\
Mulberry & Malus domestica \\
& Loquat & Morus spp \\
& Citrus & Citrus spp \\
\hline Summer fruits & Persimmon & Diosopyrus spp. \\
& Peach & Prunus persica \\
Walnut & Juglans regia \\
& Plum & Prunus communus \\
& Apricot & Prunus armeniaca \\
& Watermelon & Citrullus lanatus \\
& Almond & Prunus dulcis \\
\hline
\end{tabular}

In the Pothwar Plateau of the Punjab, A. nilotica and Zizyphus muritiana (Ber) are sometimes raised in the fields for fuel wood, timber, shade and fodder (Fig. 2). Similarly, in irrigated areas of the Punjab province, Dalbergia sissoo (Shisham) is planted for the same purposes. Such trees typically are planted on the borders of agricultural fields as shelterbelts or windbreaks (Baig et al. 1999). Agroforestry has been integral part of the farming systems in all the provinces of the country (Fig. 2). Nowadays, eucalyptus species are gaining popularity given their rapid growth and ability to thrive in areas receiving less than $300 \mathrm{~mm}$ average annual rainfall (Baig et al. 1999). 


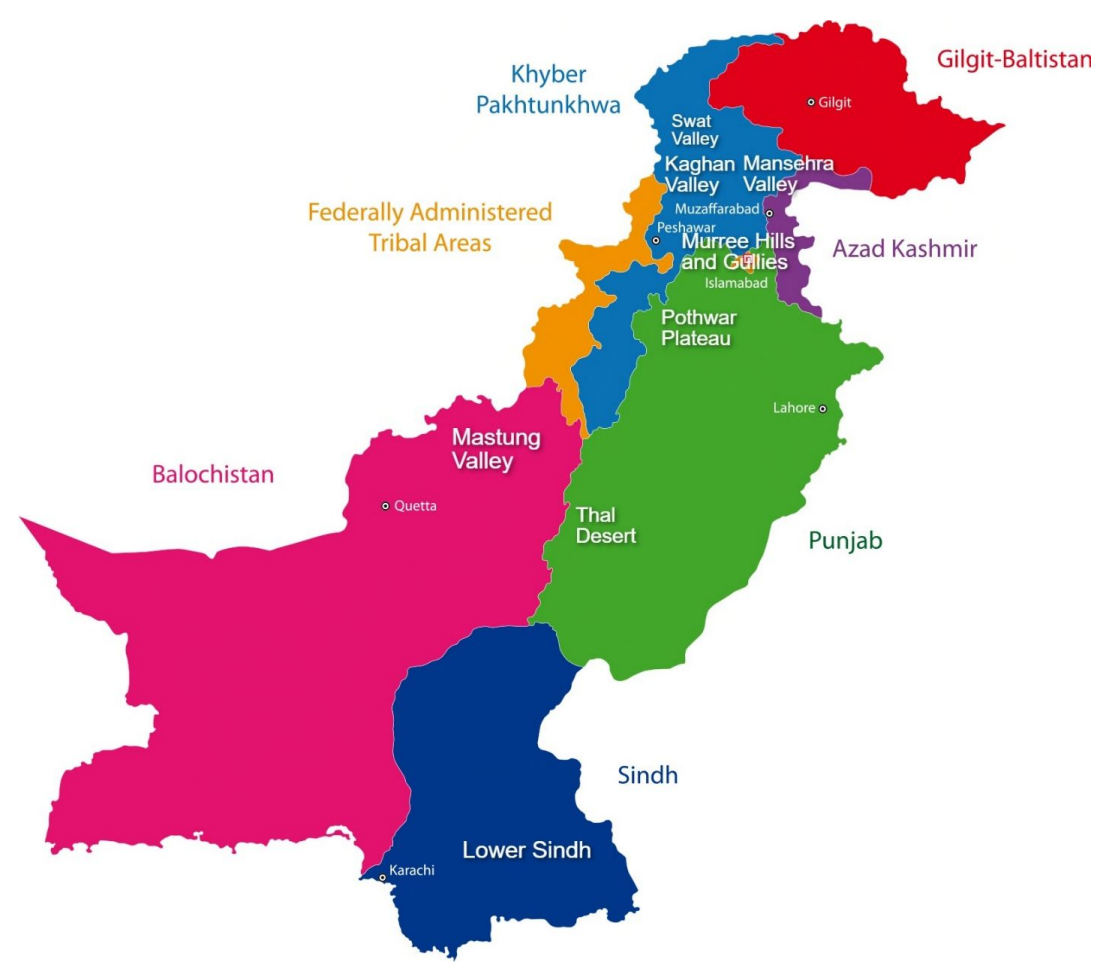

Fig. 2 Map of Pakistan indicating agroforestry initiatives taken at various locations. Map modified after Nile TV International (2019)

\section{BENEFITS OF AGROFORESTRY}

Agroforestry systems can produce a wide range of benefits in Pakistan. As in many countries with the similar set of climatic and soil factors, agroforestry provides a sizeable and significant set of services and products. The benefits of agroforestry include providing forestry products, regulating soil erosion, mitigating the effects of climate change and increasing cultural services (Fig. 3). These systems support greater farm revenue (Essa et al. 2011; Ahmad et al. 2017) and increase land productivity by sustaining food production while mitigating the negative effects of climate change, enhancing wood production, and combating land degradation. 


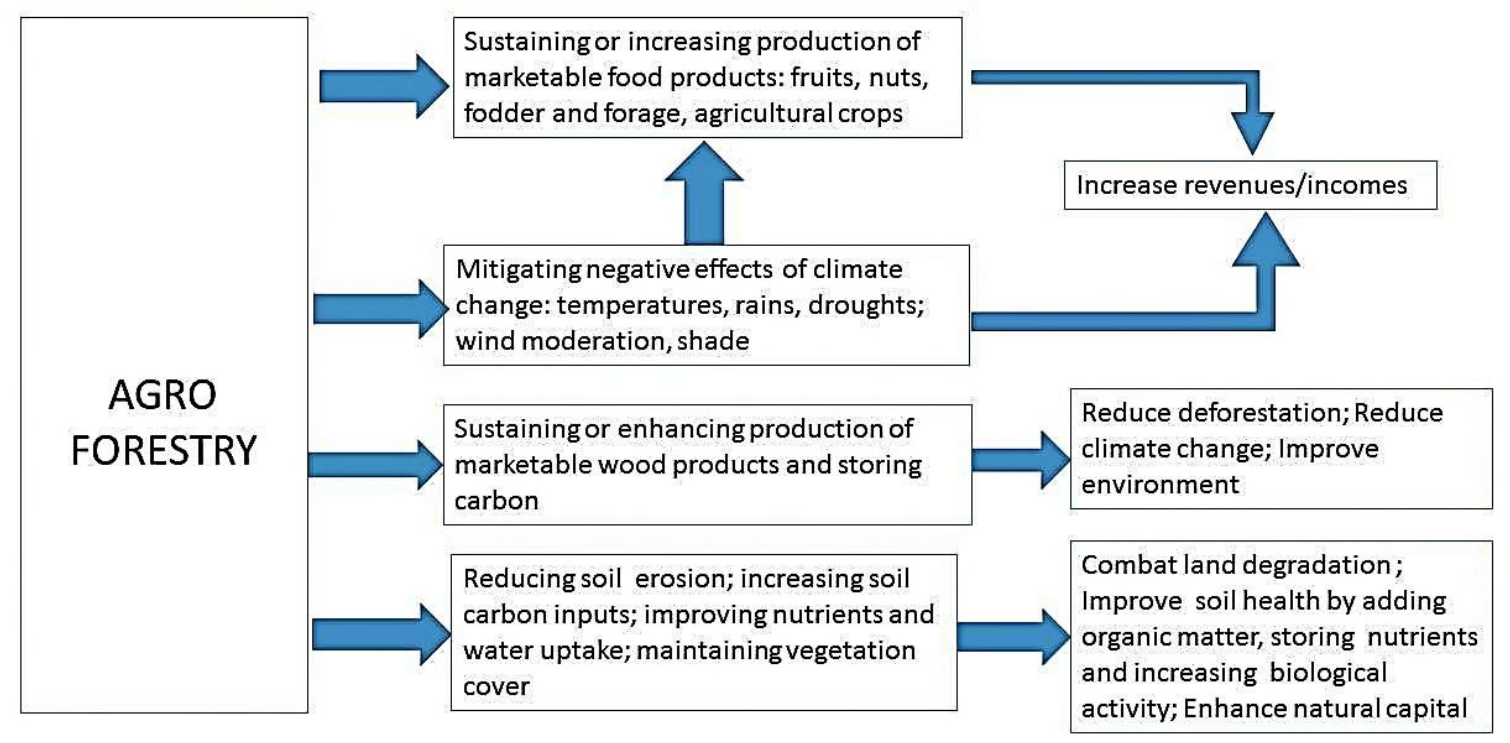

Fig. 3 Agroforestry improves production and ecosystem service functions through greater provisioning, regulating and cultural services.

\section{Maintaining or enhancing revenue from food products}

Agroforestry systems can attain higher yields than monoculture production systems by increasing the capture of solar radiation, water and nutrients by all crops in the same plot. This improves the efficiency of light, water and nutrient use. Trees can also provide additional marketable food products such as fruits and nuts. Research in South-East Asia (Roshetko and Bertomeu 2015) and Africa (Mbow et al. 2014) has demonstrated that the successful use of agroforestry can help sustain agricultural production and improve food security through the output of tree crops. It also benefits the cropping understory. Agroforestry in the form windbreaks protects croplands from hot and desiccating winds as land use system (Abbas et al. 2017). It provides food to and humans and feed to livestock, pollen for honey bees, wood for fuel, and timber for shelters and construction work. Similarly, Pakistani farmers adopting sustainable production techniques through appropriate agroforestry systems have also been able to enhance their incomes (Essa 2004; Essa et al. 2011; Magsi et al. 2014; Ahmad et al. 2017).

\section{Mitigating climate change with agroforestry}

Pakistan is predicted to be among the ten countries most affected by climate change, according to the 2019 Global Climate Risk Index (Ecksteinetal 2018). According to a report by WWF (2012) average temperatures are predicted to rise faster than most other locations, increasing $4^{\circ} \mathrm{C}$ by 
the year 2100. The country also faces an increased incidence of severe droughts and floods threatening health, agriculture and water supplies (Salam 2018).

Like many other Asian countries, farmers in Pakistan have to adapt to climate change. The effect on rainfall varies across the country; future projections anticipate increased rainfall in the Upper Indus Basin and reduced rainfall in the Lower Indus basis (ADB 2017). Agroforestry can facilitate adaptation to climate change (Vignola et al. 2015) by protecting understory crops from the increasing temperatures while reducing crop transpiration, soil evaporation, and wind speeds. Thus, to mitigate climate change effects, Pakistan has initiated a 5-year plan to plant 100 million trees under the Green Pakistan Program (Pakistan Economic Survey 2018).

\section{Agroforestry to reduce deforestation and store carbon}

There are important international targets to minimize the release of greenhouse gases and a key objective is to minimize deforestation. Trees increase aboveground carbon sequestration and also increase soil carbon on cultivated cropland (Abbas et al. 2017). Agroforestry can offset or reduce emissions caused by forest harvest or degradation through increased production of onfarm timber and fuelwood (Minang et al. 2011; Madalcho and Tefera 2016; Abbas et al. 2017). Agroforestry as a sustainable land use system has substantial potential to sequester atmospheric carbon into the soil, and in above- and below-ground biomass (Abbas et al. 2017). Asif et al. (2018) also highlighted the benefits of using agroforestry to increase tree cover outside of forested lands. These systems provide employment and increased farmer incomes while conveying environmental benefits. Rahim and Hasnain (2010) reported that about $90 \%$ of the fuelwood and $72 \%$ of the timber produced in Pakistan is derived from trees on private or community land, rather than from state owned forests. However, the estimated 330 million trees on 19.3 Mha of farmland is still insufficient to meet the national demand, which requires imports. Gilgit Baltistan, located in the upper part of Northern Pakistan covering an area of approximately 28,000 square miles $\left(73,000 \mathrm{~km}^{2}\right)$, shares borders with China, Afghanistan, and India. The province sustains very thick natural forests due to its cooler climate and high altitudes. Locals graze their animals and harvest local forests for woodfuel and timber. In order to reduce the pressure on the natural forests of the area, the government is making concerted efforts to help people plant poplar trees on their farms and lands, but due to low volume of trees on less landmass, it was not possible to meet the woodfuel needs of the locals (Khan et al. 2017).

\section{Agroforestry for combating land degradation and desertification}

Agroforestry can increase vegetative cover and thereby reduce soil erosion (Jamilu et al. 2014) and can provide a way of rehabilitating large areas of barren land in Pakistan. Degraded land is defined as land that has lost some degree of its natural productivity due to human-caused processes (WRI 2019). This usually involves negative changes in the physical, chemical, and/or biological properties of the soil, as well as vegetative degradation. Agroforestry, by increasing 
vegetative cover, represents one approach for reversing land degradation (Tolunay et al. 2007; Glover 2010).

\section{WHAT ARE THE CONSTRAINTS TO AGROFORESTRY IN PAKISTAN?}

Despite the multiple benefits of agroforestry, many farmers in Pakistan still seem reluctant to establish and sustain new agroforestry systems. Dove (1995a, b) reported that "the most important variables in the development of (agroforestry) in Pakistan are not physical but human". Zubair and Garforth (2006) also report that tree management on farms depends upon the perceptions and attitudes of the farmers. The major constraints to agroforestry in Pakistan include concerns about (i) agricultural production, (ii) a lack of markets and supplies, (iii) land designation, and (iv) technical assistance. In some locations, water shortage is a major constraint to the adoption of agroforestry.

\section{Concerns about agricultural production}

Shading by trees can reduce the level of heat stress on understory crops as well as the harmful desiccating effects of hot winds. Trees also can increase the organic matter content of cultivated soils whereas nitrogen-fixing trees can enhance soil nitrogen status (Baig et al. 1999). Despite these benefits, some farmers think that trees depress crop production due to shade, nutrient competition, and crop damage from insect pests, diseases and birds (Jamilu et al. 2014).

Although Sheikh (2001) argued that extension experts should erase such notions, greater adoption success may be realized by identifying those situations where suitable tree species meet the needs and objectives of the farmers. Though farmers know better than the extensionists where to plant and what to plant on their farms, extensionists can educate farmers which tree species are complementary to agricultural crops in terms of phenology and root architecture. For example, in windy locations increased productivity of crops distant from the tree line can offset yield depression close to the trees. Also, most trees in Pakistan are deciduous and thus leafless during winter when the sunlight is most limited. Use of tree species with narrow upright canopies (e.g. Kikar (A. nilotica) and black poplar (P. nigra) can further minimize light competition. Sheikh (2001) argued that most birds do not use trees as resting places for eating grain; rather birds can consume large quantities of harmful insects.

\section{Concerns about markets and lack of resources}

Current market structure and institutional policies limit agroforestry opportunities. Often, no established markets exist for the sale of wood and other tree products at a reference price (Jamilu et al. 2014), and thus farm foresters can be exploited by middlemen. The brokers act as a "bridge" among the farmers, foresters and timber merchants, but some do not reveal the real price of the standing trees to the foresters and the farmers. If farmers directly sold the standing 
tree poles on their farms and, if the trees are processed by the trained carpenters and timbermerchants, farmers would get higher prices for their tree lots.

Although farmers can access incentives like free seedlings and saplings, they typically want more incentives (Hasan et al. 2014) like low-cost irrigation water on their farms and no tax on agricultural crops. Farmers also want some form of security or assurance from the government that markets will be available to buy their trees and logs with appropriate and reasonable prices and will assist them in finding suitable buyers. Farooq et al. (2017) identified a lack of capital and extra cash to buy saplings, limited transportation facilities, and unreliable rootstock as important constraints. Many farm foresters and craftsmen are also not trained in the skilled use of wood-working, which limits opportunities for value addition and marketing.

\section{Poor communication and links between research and extension}

A lack of technical assistance can be a major constraint to agroforestry adoption (Farooq et al. 2017; Sheikh 2001). The constraints include absence of technology transfer mechanisms, unsupportive attitudes of foresters and administrators; limited or non-availability of trained staff; negative client responses and human behaviors and lack of follow up visits by the extensionist (Sheikh 1991, 2001). Extension staff can ensure that agroforestry is used in the right form, at the right time and in the right place with the right mix, and can improve research and outreach efforts by delivering practitioners' concerns to scientists and development agencies (Raintree 1983; Baig et al. 1999). In a traditional functional extension model, researchers and field workers develop cost-effective technologies that solve farm problems, and extension workers deliver effectively these set of technologies to the end user (Baig 1992). Lack of co-ordination and cooperation among the research, agricultural and forestry extension institutions/organizations working to help the farming community often results in the duplication of efforts and wastage of resources. Efforts in the KPK Province, a mountainous region in the Northern Pakistan (Fig. 2), make an interesting case study in this regard. A study was conducted to identify the linkages between agricultural and forestry extension services and the factors preventing effective linkages. The study revealed that both organizations were providing extension services and advice on fruit trees to the farming community yet a very weak formal and informal working relationships was noticed between both departments, making the whole exercise ineffective. The study suggested that in order to establish strong linkages between agricultural and forestry extension services, common activities must be undertaken for realizing better fruit trees (Saqib and Tachibana 2014). Such efforts may be critical for sustaining good forest cover and maintaining farming as a local livelihood. Similarly, factors like disparity in age and educational levels between farmers and extension professionals, limited numbers of field visits and weak formal linkages among various field staff make extension actives less effective (Saqib and Tachibana 2014). Lack of proper communication prevents better technologies from reaching end users. 
The foremost step is to build up a group of competent researchers and extensionists to develop the research agenda, keeping in view the national needs and priorities of the farming communities. Well designed studies also are needed that focus on identifying the problems so that researchers can set goals for research activities and design strategies and mechanisms for disseminating results to farmers practicing agroforestry (Sheikh 2001).

\section{Concerns about land designation}

Some farmers are reluctant to plant trees as they fear that foresters will take away or get control of their farmlands once the trees are established. This concern may be warranted, as most of the farmers in the uplands are not allowed to cut trees without permission from the forest department, even when planted on their own land. Similarly, in the plains, where social forestry programs are well-established, the transportation of wood from land to the sale depot or market is not allowed without a permit. Farmers view this as a big barrier and disincentive. Such policies will require immediate and suitable measures to overcome the problem and to improve the situation (Sheikh 2001).

\section{SUCCESSES AND CHALLENGES FOR AGROFORESTRY EXTENSION IN PAKISTAN}

Thal desert is situated in Southern Punjab (Fig. 2) and, due to the hot and arid climate and sandy soils, the area produces sparse vegetation of mostly thorny bushes. A successful afforestation extension campaign in the Thal desert was launched in the 1950s (Sheikh 2001). Agriculture was only possible if trees were used to fix the sand dunes and mitigate the effects of the desert's hot, sand-laden winds. New settlers were provided with free plants to establish along watercourses, on field boundaries and farm roads in single or multiple rows. An effort was made to establish a network of nurseries and to deliver the cuttings and plants at the farmers' doorstep. Sheikh (2001) noted that the dry desert was gradually transformed into a green landscape as millions of trees were planted. The same model was replicated in Sindh Province when water from the Indus River was made available for managing the province's agricultural lands (Sheikh 2001). Based on these successes, most tree extension programs in Pakistan make cuttings/plants and seedlings available to the farmers free or at nominal cost (Sheikh 2001). Several similar afforestation/reforestation initiatives were undertaken in the Himalayan foothills (high altitude areas in Northern Pakistan) and the upper plains in the Bhurban, Gullies, and Daur of Murree Hills (Fig. 2).

Another success was the expansion in the use of poplar trees in Peshawar and Mardan (both the cities in the North Western Pakistan in the KPK Province; Fig. 2) that began in 1971 where private forestry was supported with good technical support and extension services. Wattoo et al. (2010) stressed the need for strong and meaning interactions among the stakeholders to the forestry extension programs successful in the KPK province. 
Farmers realizing the multipurpose qualities of poplar continue to plant them in many areas of the Punjab and KPK provinces (KPK was previously known as NWFP), achieving reasonable financial returns (Sheikh 2001). The planting of chir pine (Pinus roxburghii) on private lands in the Kaghan and Mansehra valleys (Fig. 2) also has been successful. The Aga Khan Rural Support Program in Gilgit Baltistan of Northern Pakistan (formerly the Northern Areas) and the Forestry Planning and Development Project in the whole of Pakistan also provide encouraging examples of how mass tree planting can be motivated through incentives, education and training. Similarly, the study conducted by Hasan et al. (2014) also suggested the need for trainings of farmers and incentives/facilities to promote agroforestry in the country. In order to help farmers and promote agroforestry in the country, the Forestry Planning and Development Project was launched and it remained operational for seven years, raising more than 140 million seedlings in about 4000 farmers (kissan) nurseries (Baig et al. 1999). Of these, 92 million seedlings survived covering 40,000 ha. Additionally, development and soil conservation operations were carried out on 7000 ha (Sheikh 2001). Short courses on raising plants and field plantings were held for the farmers and junior forestry staff. Similarly, the Punjab Forest Sector Development Project helped to strengthen local public and community institutions involved in forestry management through the establishment of participatory planning and management systems and by supporting the transfer of information and technology to the end users (Sheikh 2001).

Pakistan's National Extension Service has been very successful in launching innovative programs and achieving its targets in the agricultural sector. The national agricultural extension service in Pakistan successfully supported the introduction of the Green Revolution and the spread of Mexi-Pak wheat in the 1960s (Planning Commission 1988; Axinn 1987). In a detailed examination of change at the farm level, Lowdermilk (1972) found that within six years of the introduction of the dwarf wheat, every one of the 2400 sampled farmers had tried it. By contrast, extension by forest officials has been less successful. Historically, public-funded foresters in Pakistan have functioned as regulatory officials, controlling the use of forestland (Vergara 1989; Baig and Ehrenreich 1993), and Pakistani citizens often view them as police officers (FAO 1989; Baig and Ehrenreich 1993). However, since the 1980s public-funded foresters in Pakistan have had to carry out extension activities while simultaneously enforcing the law (Baig and Ehrenreich 1993). These two contrasting functions present great challenges (Vergara 1989). In the mid to late 1980s, Pakistan launched its first nationwide agroforestry project, the Forestry Planning and Development Project, which included a forestry extension component that was expected to be provided by foresters. The objective of the project was to assist farmers with small land-holdings to grow trees on their farmlands. Since the foresters had expertise in working with trees, but not in working with farmers, the project ran into difficulties (Dove 1992). 


\section{METHODS TO SUPPORT AGROFORESTRY EXTENSION}

Several extension strategies and approaches for promoting agroforestry have been described (FAO 1985a, b, 1986, 1988; Falconer 1987; Kerkhof 1990). Scherr (1992) reported that the most appropriate extension model depends on the nature of existing constraints to agroforestry promotion. When designing these extension programs, the general principles of extension (Malik and Prawl 1993) may prove helpful for promoting agroforestry in Pakistan. Many factors can be important in making extension programs successful including: the awareness levels of the audience, the abilities and skills of the agent to deliver the message, the audience's preferred (and easily comprehended) language and educational level and the preferred methods of delivery such as TV, film, slide shows, newspapers, agricultural magazines, workshops, training, and seminars (Sheikh 1992a, b; 2001). One method of achieving successful extension is to address the seven questions stated in Table 3. Each of the questions is addressed in turn.

Table 3 Key questions in successful extension

\begin{tabular}{ll}
\hline Question & Example questions \\
\hline Extension for what purpose? & Is there a common awareness of the problem or vision? \\
Extension by whom? & Who undertakes the extension? \\
Extension for whom? & Who is the focus of the extension? \\
Extension of what? & What is the technology or innovation proposed and how is it \\
& selected? \\
Extension using what media? & What is the method for promoting a technology or innovation? \\
& Extension in what language? \\
Do you use financial incentives? & What is the role of financial incentives? \\
Extension for how long? & What are the long-term plans for extension?
\end{tabular}

\section{Sharing awareness of a problem or a vision}

Successful extension can occur when there is an awareness to address a problem or a vision to improve the current situation. Change agents need to be acquainted with their audiences, listen to their questions, and determine their current level of knowledge and needs. There is little benefit in telling people what they already know. It has been argued that whilst many farmers are aware that good fertile lands are being degraded, they are not motivated to address the problem, perhaps considering that mother nature or the government will make the situation better.

Sometimes the initiative for change can be problem-based to address issues such as overgrazing (which aggravates soil erosion), misuse of water (which causes water-logging and salinity) and inappropriate use of agrochemicals (which contaminate soils and waters) (Akbar et al. 1989a, b; Akbar et al. 1990). In rural areas of Pakistan, the lack of awareness surrounding a problem may be related to low education levels and literacy rates. In addition, a perceived problem such as deforestation may be less important than the simple day-to-day struggle of 
survival and the requirement for firewood. In a similar way, people may be closely linked to specific geographic areas and unwilling or unable to travel from their villages to see reforestation programs in their regions. Extension that is successful needs to identify such constraints, and progress can be further enhanced by producing a creative vision for positive impact (McDonough and Braungart 2013).

\section{Extension by appropriate people}

Extension agents must be sufficiently engaged and knowledgeable to respond to farmer questions (Baig et al. 1999). Moreover, given the diverse disciplines and knowledge needed for these complex, integrated systems, a willingness to work across disciplines is essential (e.g. Fikeetal.2016). While highly desirable that an extension agent be fully aware of new technologies and governmental regulations, it is more important that the person has an enquiring and active mind with knowledge of where information and best advice can be found, and an ability to reflect on what could be improved next time. Improving extension materials is likely to be a continual process. Extension materials can be made available in the form of leaflets, and in popular articles in the local languages in the agricultural magazines and daily newspapers. In the past, the messages were sent out through radio and television, and currently there are opportunities to use social media.

Farmers in Pakistan often have negative views about foresters and many foresters do not like to carry out extension activities despite incentives. The current relationship between foresters and farmers is often challenging and may be antagonistic, as many foresters have a police/control role to keep people away from state forests. Moreover, most foresters have no training in extension systems and approaches. In some cases, foresters have been appointed to extension programs as a form of establishment control (Sheikh 2001), leading to their disinterest and a lack of credibility in the eyes of the local community. In such situations, foresters can hardly have positive impacts (Sheikh 1992a, b, 2001).

The success of extension staff and transfer agents depends on their being trustworthy and honest. No matter how good the information might be, its acceptability to the end user depends to a large extent on a relationship of mutual trust and confidence. This may require both the dismantling of social barriers and appropriate humility from extension agents. Without a respectful relationship it is difficult to motivate others to adopt improved technologies and approaches that could improve their well-being (Sheikh 2001). Although Pakistan has both forestry and agricultural extension workers, the country faces an acute shortage of well-trained agroforestry specialists (Mohammad and Ehrenreich 1993; Baig and Ehrenreich 1993; Baig et al. 1999). One option would be to provide in-service training to extensionists from both departments, bringing together foresters and agriculturists, along with social scientists to facilitate understanding and building relationships (Vergara 1989; Baig and Ehrenreich 1993). 
There may also be a specific need for leadership training and skills to facilitate partnerships and co-operation across disciplines (Brooks et al. 1994).

\section{Identification of target persons/groups}

Successful extension programming also depends on extension workers correctly identifying the specific requirements of important target groups. Yocco (2015) argues that innovations do not necessarily diffuse automatically from one social group to another. For example, small farmers are unlikely to visit a large farmer having trees; nor would a tenant (hari in local terms) in Sindh or buzdar in Balochistan Province have the courage to talk to the sardar (landlord) about tree planting. On the other hand, Baig et al. (1999) argue that the approaches of trickledown theory and farmer-to-farmer exchanges can be successful, as evidenced in the Green Revolution. These approaches included meetings with the interested farmers and sharing examples of successful innovation (FAO 1997). Progressive farmers in Pakistan are generally willing to cooperate and participate in trying innovations like agroforestry (Baig et al. 1999). They also typically have the resources to take care of demonstration plots and the capacity to afford the risk of project failure.

Extension workers should also be aware of potential bias in the selection of target groups. For example, the value of many upland watershed management projects might be questioned as the benefits of these programs may go largely to wealthier peoples or communities living in the plains. In fact, deriving benefits for upstream communities may require a different approach, such as the promotion of small scale industries, improved marketing facilities, health care facilities or development of clean drinking water supplies (Sheikh 2001).

\section{Providing farmers with superior technologies and essential resources}

Farmers are only likely to be interested in agroforestry if it can improve their productivity and socio-economic conditions (Vergara and MacDicken 1990). Identifying such agroforestry practices can be achieved by multi-disciplinary teams (Brooks et al. 1994) that use a participatory approach (Akbar et al. 2000). This focus on participatory innovation matches a similar shift in the role of participation in forest governance in Pakistan (Shahbaz et al. 2012).

Vergara and MacDicken (1990) and Dove (1992) also argue that involving farmers in all phases of extension-right from the planning (based on their needs and requirements) to the monitoring and evaluation - can help ensure both a sense of ownership of and achievement from the efforts. This can be challenging, however, as Pakistan's targets and priorities currently are set by extension personnel at their institutional meetings (Dove 1992), whereas farmers set their own agendas in their homes (Nayman 1990). When farmers' interests do not match those of the extensionists, extension efforts are likely to be ineffective and inefficient (Baig and Ehrenreich 1993).

In such situations, farmers can still benefit from straightforward technical information. For instance, a farmer in Pakistan seeking to restore marginal land under trees-instead of using 
it only for grazing-will require information on sources of seeds or seedlings, method of planting, site and species suitability, nitrogen fixation potential, post-establishment care, pest management and best management for the tree crop interface. They will also require information about potential markets for tree products and their likely yield and value (Jamilu et al. 2014; Farooq et al. 2017). In such cases, an extension worker should be knowledgeable enough to prepare a comprehensive package of technology for the end-users. Such tree planting packages become more acceptable if a participatory approach is adopted between the transfer agent and the farmer (Akbar et al. 2000; Sheikh 2001).

\section{Selection of the most appropriate media}

The selected medium should be adapted to the message, the characteristics of the target audience (e.g. level of knowledge, needs) and the social environment (Wete 1991). In general, extension messages should be phrased in the simplest, most understandable forms. Other important criteria are the accessibility to the target groups and cost involved (Hedge 1989; Baig and Ehrenreich 1993). Nayman $(1988,1990)$ found that Pakistani farmers were vigorous seekers of information, using a range of methods to gather new agricultural knowledge to improve their farm businesses.

The most common sources were fellow farmers (91\%) and private market representatives (65\%). For non-personal communication, the low literacy rate favors the use of pictorial media to deliver messages (Baig and Ehrenreich 1993; (Baig et al. 1998, 1999). Examples of the main media forms include:

\section{Face-to-face communication}

Such communication between experienced practitioners and individuals or groups has long been effective in the rural societies of Pakistan. Some well-trained and trusted extension workers are very able to inspire and encourage farmers to action. In some contexts, imams and other religious leaders will even allow extension workers to address prayer congregations in masjids (mosques) and other worship centers (Sheikh 2001).

\section{Use of print and electronic media}

The highly diversified geography, widely dispersed extension sites, and difficulty in accessing target clients, has meant that agroforestry extension in Pakistan frequently relies on newspapers, posters, radio, television, and slide shows. These can be effective and efficient extension tools for delivering messages and technical information (Baig and Ehrenreich 1993; Baig et al. 1999; Wattoo et al. 2010; Baig and Aldosari 2013). Radio and other electronic media may be most effective, however, given lower literacy rates among rural communities. 


\section{Demonstration plots and model farms}

Most farmers are kinesthetic learners and hence practical, hands-on demonstrations are very effective. For example, demonstrations of poplar wood lots in the province of KPK (Fig. 2), eucalyptus windbreaks in Sindh, and agroforestry in irrigated plains of the Punjab all have been instrumental in establishing a measure of credibility for agroforestry and they have helped to encourage and motivate farmers to plant trees.

Similarly, farmers that have adopted the technology of reseeding wastelands with useful and nutritious grasses can be presented as examples to other farmers who keep cattle, sheep and goats. Farmers of the area have been impressed seeing fields duly reseeded successfully by fellow farmers (Sheikh 2001). Demonstration plots can be particularly successful when they are grown on a farmer's fields using his or her resources (Baig and Ehrenreich 1993) and facing similar constraints (Baig et al. 1998, 1999). Brennan (1989) reported that using farmers and their ideas also leads to more effective and worthwhile development. Demonstration sites can also be used to teach neighboring farmers, increasing motivation and awareness (Baig et al. 1998, 1999). In the specific case of agroforestry, model farms at the village level could be effective in promoting these systems. Although resource limitations may preclude a model agroforestry farm in each village, the Government of Pakistan should, at least, try to establish agroforestry model farms at the union council level (Baig and Ehrenreich 1993; Baig et al. 1999).

\section{Vocational agroforestry training and education}

Vocational level or sub-professional level training and education in agroforestry, soil and water conservation, extension approaches, and rural development would be helpful (Sheikh 2001). This would be in the form of short training programs for small groups focused on local projects. Print and electronic media outlets can also be used to publicize watershed management problems and promote solutions, and this subject should be incorporated into school curricula and textbooks.

\section{Web-sites and social media}

Websites can offer highly effective and cost-effective means of providing information and social media can be used to increase awareness. For example, the AGFORWARD website (www.agforward.eu) has been effective in promoting agroforestry in Europe (Burgess and Rosati 2018). The theme of the message may vary according to the level of participation and stage of the project. Messaging during the initial stage of the project should be attractive enough to capture the attention of the farmers that participate in the agroforestry program. However, subsequent messaging might concentrate on increasing productivity, conserving natural resources and strengthening infrastructure (Hedge 1989; Baig et al. 1998, 1999). 


\section{Choice of language}

In Pakistan, where several languages are spoken and scores of dialects exist, delivery of the message in English, which is understood by less than $30 \%$ of the population of the country, can be unproductive. Each of the five provinces of Pakistan (Punjab, Gilgit Baltistan, Balochistan, Khyber Pakhtunkhwa, and Sindh) and the independent territory of the State of Azad Jammu and Kashmir has its own language. For more effective delivery, messages should be developed in the local language. This would enable local extension agents to deliver the agroforestry message more effectively than when the message is delivered by an agent unfamiliar with the culture, traditions and norms of target clientele (Baig 1992; Baig and Ehrenreich 1993). Delivering information in a local language that is easily understood-in a precise manner without long narratives-improves the chance of acceptance.

\section{Role of financial incentives}

Financial benefit is an important driving force in determining whether farmers adopt an innovation. A farmer is more likely to be interested in the personal benefit of producing a wood crop that can be sold at a profit in 5-8 years, rather than by a national need to bridge the gap between wood supply and demand. Offering early adopters incentives or subsidies can support agroforestry uptake (Vergara and MacDicken 1990; Baig and Ehrenreich 1993). The subsidies can include developmental loans at low interest rates (Aquino et al. 1987), free seedlings and technical advice or tax credits for the cost of establishing agroforestry farms from their income taxes. The potential benefits and costs of such support should be ascertained before implementation (Baig and Ehrenreich 1993; Baig et al. 1999). An alternative means of support is to strengthen the transparency of the market for tree products. A strong linkage and good working relationship between wood producers and wood users would go a long way toward improving market confidence.

\section{Long-term institutional support}

Farmers rarely adopt innovations in the absence of technical, financial and administrative support. Limitations in terms of information, loans, inputs, or timely advice on field operations only serve to discourage. Successful extension benefits from long-term institutional support and the conscientious commitment of extension workers who are aware of local cultures, norms, traditions and ways of life (Baig et al. 1999). Because of the multi-disciplinary nature of agroforestry, extension workers need to adopt principles and practices that combine elements of anthropology, economics, agronomy, animal husbandry, sociology and forestry (Sheikh 2001) in order to meet the expectations of the farmers. Pakistan has launched many forestry extension projects under different slogans (e.g. "farm forestry initiatives for farmers", "social forestry for social development", and "community forestry for sustainable communities"). Although new 
projects are implemented for a certain period, there is no long-term follow-up and evaluation; hence the impact of such projects gradually disappears with the passage of time (Sheikh 2001).

\section{RECOMMENDATIONS}

This paper has outlined the challenges to and the potential for agroforestry practices in Pakistan to improve the country's resources through both production and conservation functions. To achieve such outcomes, agroforestry extension must serve as a process that involves the identification of constraints and objectives, meets the needs of facilitators and end users, provides potential innovations and available resources, and supports appropriate communication pathways within a reflective institutional framework (Table 4).

Table 4 Some recommendations for agroforestry extension in Pakistan

\begin{tabular}{|c|c|}
\hline Question & Recommendations \\
\hline Extension for what purpose? & $\begin{array}{l}\text { The challenges and vision for agroforestry development } \\
\text { should be co-developed by extension workers and end-users. }\end{array}$ \\
\hline Extension by whom? & $\begin{array}{l}\text { To develop and train a cohort of agroforestry extension } \\
\text { workers who can bridge the work of agricultural and forestry } \\
\text { departments. The cohort should be able to draw on trained } \\
\text { indigenous knowledge specialists and engage with existing } \\
\text { agencies, local religious and community leaders, non- } \\
\text { Government Organizations (NGOs) and cooperative societies. }\end{array}$ \\
\hline Extension for whom? & $\begin{array}{l}\text { To primarily focus on farmers, recognizing the need to engage } \\
\text { positively with both youth and women. }\end{array}$ \\
\hline Extension of what? & $\begin{array}{l}\text { To use a participative approach, that empowers local } \\
\text { communities, to prioritize agroforestry initiatives. Some } \\
\text { issues such as developing nurseries and advising on planting, } \\
\text { species selection and harvest and marketing methods will be } \\
\text { technical and will draw on the experience for example of the } \\
\text { Forestry Department. However, some extension may focus on } \\
\text { land tenure and property rights. The programs should have } \\
\text { some flexibility and be evaluated regularly. }\end{array}$ \\
\hline Extension using what media? & $\begin{array}{l}\text { Inclusion of agroforestry topics in school and college curricula } \\
\text { to promote appreciation of trees. Engagement of TV, radio } \\
\text { and print are effective. FM radio stations have a wide } \\
\text { audience. }\end{array}$ \\
\hline Do you use financial incentives? & $\begin{array}{l}\text { Where appropriate, incentivize and provide credit facilities } \\
\text { for agroforestry practices. There may be rebates on water } \\
\text { charges and land revenues particularly in irrigated cultivated } \\
\text { areas. }\end{array}$ \\
\hline Extension for how long? & $\begin{array}{l}\text { Increase institutional support for the desired objectives, in } \\
\text { line with government policy to increase food supply and } \\
\text { eradicate poverty in rural areas. }\end{array}$ \\
\hline
\end{tabular}


A similar focus on problem-orientated research, technology packages and diffusion, and the need to monitor and evaluate was also described by Vergara and MacDicken (1990). The review has highlighted that the problems and vision associated with agroforestry development should be co-developed with end-users (Coe et al. 2014). Extension recommendations should follow from the considerations laid out in Table 4 and may encompass any range of needs.

In some cases, the challenge for agroforestry extension may be to increase farmer awareness of the on-farm benefits of agroforestry in terms of increased revenue and soil conservation (Jamilu et al. 2014; Farooq et al. 2017). In others, the provision of planting material to support implementation will be most important (Jamilu et al. 2014). Sometimes greater guidance and promotion will be needed to increase awareness of the opportunities with different tree crops, with indigenous species as a particular focus (Farooq et al. 2017). Other topics would include credit availability (Amare et al. 2018) and identification of opportunities outside of farming (Sujakhu et al. 2018). The choice of media needs to be undertaken with awareness that literacy and educational opportunities for many farmers have been limited. The benefits of trees should be included in school curricula and awareness can be promoted through local competitions. The widespread use of demonstration plots within villages and of agroforestry model farms at a union council level is recommended.

In terms of institutional change, we argue that there is a need to invest in a dedicated cohort of extensionists who can work and communicate effectively with members of both the forest and agricultural sectors (Baig et al. 1999), and that this group would benefit from specific agroforestry training (Anwar et al. 2017). Such initiatives could also help to support greater coordination between forestry and agricultural departments (Anwar et al. 2017).

In many cases, there will be an overall societal benefit for the government to provide initial subsidies or grants to promote agroforestry and increase the market opportunities for tree products from farmland (Anwar et al. 2017; Jamilu et al. 2014; Rasul and Hussain 2015; Farooq et al. 2018). In some cases, addressing land tenure or the facilitation of working relations between landowners and tenants will be important (Anwar et al. 2017). In some locations there is a need to address rules and regulations that hinder the movement of goods (e.g. poplar wood) between provinces (Shaikh 2000; Rahim and Hasnain 2010). Lastly, institutional change can be promoted through the strengthening of research and development that indicates how agroforestry can help support national objectives related to poverty reduction, food security and climate change.

\section{CONCLUSIONS}

At present, food and fuel supplies in Pakistan are not keeping pace with the needs of an increasing population. There is an immediate need to raise awareness of the benefits of agroforestry (in terms of income, soil improvement and climate moderation) among the potential 
users. The appropriate integration of trees on farms can maintain food production, minimize land degradation and provide additional sources of revenue. However, agroforestry practices and systems are diverse and complex, and reflect the cumulative innovations, experimentation, and knowledge that farmers have evolved over centuries. Going forward, it is important to work with individual farmers to identify which agroforestry practices are most appropriate for a given farm. Extension workers therefore need to be trained in diagnosing the need of farmers and identifying possible agroforestry designs to address those needs. Since much of the rural population is illiterate, pictorial media are often more helpful than print media. Development of model agroforestry farms at the village level or, at least, at the union council level is also recommended. Dedicated extension efforts made by the Government of Pakistan are commendable and should prove fruitful, particularly with economic incentives, but will require sustained effort and evaluation. Now is the time for extension workers and farmers to work together with researchers and policy makers to move agroforestry in Pakistan forward.

\section{Acknowledgements}

The authors would like to thank THE Research Center at College of Food and Agriculture Sciences and the Deanship of Scientific Research at the King Saud University, Saudi Arabia for supporting this work. The authors are also very thankful to Dr. Michael Reed, Professor, Agricultural Economics and Director, International Programs for Agriculture, University of Kentucky Lexington, KY USA for his review, able input and editing of the article.

\section{References}

Abbas F, Hammad, HM, Fahad S, Cerdà A, Rizwa M, Farhad W, Ehsan S, Bakhat HF (2017) Agroforestry: a sustainable environmental practice for carbon sequestration under the climate change scenarios-a review. Environ Sci. Pollut. Res. Int. 24: 1117711191.http://doi: 10.1007/s11356-017-8687-0. Epub 2017 Mar 9.

ADB (2017) Climate change profile of Pakistan. Prepared by: Qamar Uz Zaman Chaudhry; International Climate Technology Expert. ISBN 978-92-9257-721-6 (Print), 978-92-9257722-3 (e-ISBN) Publication Stock No. TCS178761 DOI: http://dx.doi.org/10.22617/TCS178761; https://www.adb.org/sites/default/files/publication/357876/climate-changeprofilepakistan.pdf

Ahmad A, Shahbaz B, Shehzad M, Khursheed K, Aftab M (2017) Analysis of performance of farm forestry and its role in household income in district Faisalabad, Pakistan. J. Glob. Innov. Agric. Soc. Sci. 5: 39-42. ISSN (Online): 2311-3839; ISSN (Print) 2312-5225. DOI: https://doi.org/10.22194/JGIASS/5.1.762

Akbar G, Ashraf MM, Ahmad M (1989a) Agroforestry: A new horizon for wood production and increased farm income-I. Sustainable development - A challenge in Pakistan. Progressive Farming. 9:32-38.

Akbar G, Ashraf MM, Ahmad M (1989b) Agroforestry: A new horizon for wood production and increased farm income-II. History and future prospects. Progressive Farming. 9:32-40 
Akbar G, Ashraf MM, Ahmad M (1990) Agroforestry: A new horizon for wood production and increased farm income-III. Role in ecosystem sustainability. Progressive Farming. 10: 3037

Akbar G, Baig MB, Asif M (2000) Social aspects in launching successful agroforestry projects in developing countries. Science Vision 5: 52-58

Ali A, Rahut DB, Imtiaz M (2017). Implications of less tail end water on livelihoods of small farmers in Pakistan. Outlook Agric 46: 36-43.

Amare D, Wondie M, Mekuria W, Darr D (2018) Agroforestry of smallholder farmers in Ethiopia: Practices and Benefits. Small-scale For https://doi.org/10.1007/s11842-018-9405-6

Anwar F, Jamil M, Fahad S, Khan A (2017) Role of agroforestry in wood production and farmer's perception in Pakistan: A Review. American-Eurasian J. Agric. Environ. Sci 17:300-306. Available at: https://www.idosi.org/aejaes/jaes17(4)17/6.pdf

Aquino R, Del Castillo RA, Payuan E (1987) Mounting a National Social Forestry Program: the Philippine experience. Working paper. East-West Centre, Honolulu, HI, USA

Asif ER, Hussain S, ljaz M, Niaz N (2018) Agroforestry: Needs and practices for adoption in Pakistan. Available at: https://agrihunt.com/articles/pak-agrioutlook/agroforestryneedsand-practices-for-adoption-in-pakistan/

Axinn GH (1987) The different systems of agricultural extension education with special attention to Asia and Africa. In: Rivera WM. and Schram SG (Eds) Agricultural Extension Worldwide Issues, Practices and Emerging Priorities. Croom Helm, New York, USA

Baig MB (1992) Technology transfer and agricultural extension in Asian countries. M.S. Thesis, Utah State University, Logan, USA

Baig MB, Aldosari F (2013) Agricultural extension in Asia: constraints and options for improvement. J. Anim Plant Sci 23(2): 619-632

Baig MB, Ehrenreich JH (1993) Promoting agroforestry through extension: A Pakistan example. In: Schultz RC, Colletti JP (Eds) Proc. Third North American Agroforestry Conference. Ames, lowa. pp 283-286

Baig MB, Ehrenreich JH (1997) The potential prospects and problems of agroforestry in Pakistan-1: Research and Development. Pak J Agri Sci 34:22-28.

Baig MB, Khan MA, Sultani MI (1998) Agroforestry as a farming system in Pakistan: potential and problems. Sci. Vision 3:25-34.

Baig MB, Akbar G, Straquadine GS, Razzaq A (1999) Agroforestry extension and technology transfer to farmers in Pakistan Sci. Vision 5:42-50.

Brennan E (1989) Using farmers and their ideas for effective extension work: a case study from Thailand. In: Proc. Int. Conf. on MPTS Research for Small Farms: Strategies and Methods. Jakarta, Indonesia. pp 94-97

Brooks KN, Gregersen HM, Ffolliott PF (1994) Role of agroforestry in sustainable land-use systems. In: Rietveld WJ (Ed) Agroforestry and Sustainable Systems: Symp. Proc. USDA Forest Service. General Technical Report RM-GTR 261. pp 99-205

Burgess PJ Rosati (2018) Advances in European agroforestry: results from the AGFORWARD project. Agrofor Syst 92: 801-810

Chaudhry AA (2011) Forest and climate change. Report on World Environment Day, June 16. 
Coe R, Sinclair F, Barrios E (2014) Scaling up agroforestry requires research 'in' rather than 'for' development. Curr Opin Environ Sustain 6:73-77.

https://doi.org/10.1016/i.cosust.2013.10.013

Dove MR (1992) Forester' beliefs about farmers: a priority for social science research in social orestry. Agrofor Syst 17:13-41

Dove MR (1995a) The human-ecological background of farm forestry development in Pakistan. In: Farm forestry in South Asia. Saxena NC, Ballabh V (eds.) Sage Publications. London UK

Dove MR (1995b) The shift of tree cover from forests to farms in Pakistan: A long and broad view. In: Tree management in farmer strategies: Responses to agricultural Intensification Arnold JEM, Dewees A (Eds.) Oxford University Press Oxford UK

Eckstein D, Hutfil ML, Winges M (2018) Global climate risk index 2019. Who suffers most from extreme weather events? Weather-related loss events in 2017 and 1998 to 2017. Germanwatch. https://germanwatch.org/sites/germanwatch.org/files/Global\%20Climate \%20Risk\%20Index\%202019 2.pdf Accessed on 19 February 2019.

Essa M (2004) Household income and natural forest conservation by agroforestry: an analysis based on two agroecological zones: Bagrot and Jalalabad in Northern Pakistan. MSc Thesis Norwegian University of Life Sciences, Norway.

Essa M, Nizami SM, Mirza SN, Khan IA, Athar M (2011) Contribution of agroforestry in farmers' livelihood and its impact on natural forest in Northern Areas of Pakistan. African J Bio. 10:15529-15537. http://DOI: 10.5897/AJB09.1067

FAO (1985a) Tropical forestry action plan. Committee on Forest Development in the Tropics. Food and Agriculture Organization of the United Nations. FAO, Rome. 159 p.

FAO (1985b) Tree growing by rural people. FAO Forestry Paper 64. Food and Agriculture Organization of the United Nations. FAO, Rome. 130 p.

FAO (1986) Forestry extension organization. FAO Forestry Paper No. 66. Food and Agriculture Organization of the United Nations. FAO, Rome.

FAO (1988) Planning forestry extension programs. Regional Wood Energy Development Program in Asia, GCP/RAS/111/ NET Field Document No. 8. Food and Agriculture Organization of the United Nations. FAO, Bangkok. 199 p.

FAO (1989) Forestry and food security. FAO Forestry Paper No. 90. Food and Agriculture Organization of the United Nations. FAO, Rome.

FAO (1997) Improving agricultural extension. A Reference Manual. 3rd Edition, Food and Agriculture Organization of the United Nations. FAO, Rome

FAO (2015a) Global forest resource assessment 2015. Desk Reference. Food and Agriculture Organization of the United Nations. Rome. Available online at: http://www.fao.org/3/ai4808e.pdf. Accessed on 22nd January 2018

FAO (2015b) Agroforestry. Food and Agriculture Organization of the United Nations. Rome. Available online at: http://www.fao.org/forestry/agroforestry/80338/en/ . Accessed on Nov. 6, 2019

Farooq TH, Nawaz MF, Khan MW, Gilani MM, Buajan S, Iftikhar J, Tunon N, Wu P (2017) Potentials of agroforestry and constraints faced by the farmers in its adoption in District Nankana Sahib, Pakistan. Int. J of Dev Sustainability 6: 586-593

Farooq TH, Gautam NP, Rashid MHU, Gilani MM, Nemin W, Nawaz MF, Islam W, Zainab M, Wu $P(2018)$ Contributions of agroforestry on socioeconomic conditions of farmers in central 
Punjab, Pakistan - A case study. Cercetări Agronomice în Moldova. 51:91-101. DOI: 10.2478/cerce-2018-0020

Fike J, Downing A, Daniel JB, Teutsch C, Mercie K, Pent G (2016) Creating silvopastures: some considerations when thinning existing timber stands. Virginia Cooperative Extension Publication CES-155.

http://digitalpubs.ext.vt.edu/vcedigitalpubs/8513366315849431/MobilePagedReplica.act ion?

Garland EA (1944) Experiments in alternating husbandry in Sind. Indian Farming 5:495-498.

Glover EK (2010) Approaches to halt and reverse land degradation in Kenya: Agroforestry development and environmental sustainability. Germany, VDM Verlag, Germany.

GOP (2003) Economic Survey of Pakistan 2002-2003 Government of Pakistan. Islamabad, Pakistan

GOP (2013) The state of environment of Pakistan, Report, pp. 35-77

Hasan G, Ashraf I, Mehmood CK, Sagheer A, Irshad MQ (2014) Present and future prospects of agroforestry as perceived by farmers in Punjab, Pakistan. Int Asian Res J 2:11-17

Hedge NG (1989) Extension and training needs to motivate small scale farmers. In: Proc. Int. Conf. on MPTS Research for Small Farms: Strategies and Methods. Jakarta, Indonesia. pp 98-102

Jamilu A, Ammar H, Gardish DM (2014). Factors upsetting agroforestry system in Swat, Pakistan. Int J Agrofor and Silviculture 1:86-92. Available online at: www.internationalscholarsjournals.org

Kerkhof P. 1990. Agroforestry for development in Kenya: A Survey of Project Experience. Panos Institute, London. UK 216 p.

Khan M, Mahmood HZ, Abbas G, Damalas CA (2017) Agroforestry systems as alternative landuse options in the arid zone of Thal. Pakistan. Small-scale For 16: 553-569.

Lowdermilk, M.K. (1972) Diffusion of dwarf wheat production technology in Pakistan's Punjab. Ph.D. Thesis. Cornell University, Ithaca, New York.

Madalcho AB, Tefera MT (2016) Management of traditional agroforestry practices in Gununo Watershed in Wolaita Zone, Ethiopia. Forest Res 5: 163. doi:10.4172/2168-9776.1000163

Magsi H, Lohano HD, Mirani ZU (2014) Marketing system and structure for agroforestry products in Sindh, Pakistan. Euro Aca Res 2(7): $9509-9522$

Mahmood HZ, Qasim M, Khan M, Husnain MIU (2014) Re-examining the inverse relationship between farm size and productivity in Pakistan. The J of Ani \& Pla Sci 24:1537 1546. ISSN: 1018-7081

Malik W, Prawl W (1993) Reforming agricultural extension in Pakistan. In: Proc. National Workshop on Reforming Agricultural Extension in Pakistan. FAO, UNDP and Pakistan Agricultural Research Council, Islamabad. Pakistan. pp13-42.

Mbow C, van Noordwijk M, Prabhu R, Simons T (2014) Knowledge gaps and research needs concerning agroforestry's contribution to sustainable development goals in Africa. Curr Opin Environ Sustain 6:162-170 https://doi.org/10.1016/j.cosust.2013.11.030

McDonough W, Braungart N (2013) The Upcycle: Beyond Sustainability - Designing for Abundance. North Point Press. New York USA 
Minang PA, Bernard F, van Noordwijk M, Kahurani E (2011) Agroforestry in REDD+: opportunities and challenges. ASB Policy Brief No. 26, ASB Partnership for the Tropical Forest Margins, Nairobi, Kenya

Mohammad A, Salim M (1989) Soil quality and sustainability aspects of low input agriculture in semiarid regions of Pakistan. In: Proc. Int. Cong. on Soil Quality in Semiarid Agriculture. Sasktoon Canada, pp196-215

Mohammad T, Ehrenreich JH (1993) The scope and development of agroforestry in Pakistan. In: Schultz RC, Colletti JP (Eds.) Proc. Third North American Agroforestry Conference. Ames, lowa USA, pp 377-379

Nair PKR (1993) An introduction to agroforestry. Kluwer Academic Publishers, Dordrecht, The Netherlands. pp 1-440.

Nayman OB (1988) Seekers of light. An evaluation of official and non-official sources of agricultural information. Lahore, Punjab, Pakistan.

Nayman OB (1990) Distant cousins. An evaluation of official and non-official sources of agricultural information. Lahore, Punjab, Pakistan.

Nile TV International (2019) Map of Pakistan. http://www.nileinternational.net/en/?p=58583

Pakistan Economic Survey (2013-14) Environment. Chapter 16. Ministry of Finance, Government of Pakistan, Islamabad, Pakistan. pp 245-256. http://www.finance.gov.pk/survey/chapters 14/16 Environment.pdf

Pakistan Economic Survey (2018-19) Education. Chapter 10. Ministry of Finance, Government of Pakistan, Islamabad, Pakistan. http://www.finance.gov.pk/survey/chapters 19/10Education.pdf

PARC (2019) Agro-ecological zones of Pakistan. Agricultural maps of Pakistan. Available at: http://www.parc.gov.pk/index.php/en/component/content/article/43-maps/19-agrimaps

PBS (2017) Pakistan Bureau of Statistics. Provisional summary results of 6th population and housing census -2017. Available at: http://www.pbs.gov.pk/content/provisionalsummaryresults- 6th-population-and-housing-census-2017-0 Accessed on 22 January 2018

Planning Commission (1988) Seventh Five-Year Plan 1988-93 and Perspective Plan. Ministry of Planning. Government of Pakistan, Islamabad.

Rahim SMA, Hasnain S (2010) Agroforestry trends in Punjab, Pakistan. Afr J of Env Sci. Tech 4:639-650. Available online at http://www.academicjournals.org/AJEST

Raintree JB 1983. Strategies for enhancing adoptability of agroforestry innovations. Agrofor Syst 1:173-187.

Rasul G, Hussain A (2015) Sustainable food security in the mountains of Pakistan: towards a policy framework. Ecology of Food and Nutrition 54:625643http://DOI:10.1080/03670244.2015.1052426

Roshetko JM, Bertomeu M (2015) Multi-species and multifunctional smallholder tree farming systems in Southeast Asia: timber, NTFPs, plus environmental benefits. Ann Silvic Res 39: 62-69. Available online at:

https://journalscrea.4science.it/index.php/asr/article/view/1125/pdf

RWEDP (2000) Woodfuel production and marketing in Pakistan: National Workshop 1997, Regional Wood Energy Development Programme, 2000. Food and Agriculture Organization of the United Nations. FAO, Bangkok. Thailand. 
Salim A (2018) Pakistan is ground zero for global warming consequences. Article published in "USA Today" on July 242018.

Saqib R, Tachibana S (2014) Contribution of agricultural and forestry extension services to inclusive extension system in North-West Pakistan: a case study of Mansehra and Swat districts of Khyber Pakhtunkhwa Province. J Agric Ext Rural Dev 6:175-187.

Scherr SJ (1992) The role of extension in agroforestry development: evidence from Western Kenya. Agrofor Syst 18:47-68.

Shahbaz B, Ata S (2014) Agricultural extension services in Pakistan: challenges, constraints and ways forward. Background Paper No. 2014/1. Enabling agricultural policies for benefiting smallholders in dairy, citrus and mango industries of Pakistan - Project No. ADP/2010/091.

Sheikh MI (1987) Agroforestry in Pakistan. In: Khosla PK, Khurana DK (eds.) Agroforestry for rural needs, Vol. 1. Indian Society of Tree Scientists, Solan

Sheikh MI (2001) Deficiencies in forestry extension programs in Pakistan: constraints and opportunities. In: Woodfuel Production and Marketing in Pakistan. RWEDP Report No. 55, Report of the National Workshop Held in Hyderabad, Sind, Pakistan, 20-22 Oct. 1998. Food and Agriculture Organization of the United Nations. FAO, Bangkok, Thailand. pp158171.

Tolunay A, Alkan H, Korkmaz M, Filizzbïlgïn S (2007) Classification of traditional agroforestry practices in Turkey. Int J Nat and Eng Sci 1:41-48.

Vergara NT (1989) Solution in search of problems: research/extension constraints in small scale farm forestry. In Proc. Int. Conf. on MPTS Research for Small Farms: Strategies and Methods. Jakarta, Indonesia. pp 82-88

Vergara NT, MacDicken KG (1990) Extension and agroforestry technology delivery to farmers. In: MacDicken KG, Vergara NT (Eds.) Agroforestry Classification and Management. John Wiley and Sons. New York, USA. pp 354-373

Vignola R, Harvey CA, Bautista-Solis P, Avelino J, Rapidel B, Donatti C, Martinez R (2015) Ecosystem based adaptation for smallholder farmers: definitions, opportunities and constraints. Agric Ecosyst Environ 211:126-132. https://doi.org/10.1016/j.agee.2015.05.013

Wattoo MA, Ali T, Khan MAJ, Shahbaz B (2010) Stakeholders' role and interactions in context of forestry extension interventions in the northwest Pakistan. Pak J Agric Sci 47:173-177.

Wete FN (1991) New technology for transferring agricultural information. In: Rivers WM, Gustafson DJ (Eds.) Agricultural Extension: World-wide Institutional Evolution and Forces for Change. Elsevier, New York.

World Bank. (2018a) Population density. Available at: https://data.worldbank.org/indicator/EN.POP.DNST. (Accessed 22 January 2018.)

World Bank. (2018b) Population ranking. Available at: https://data.worldbank.org/datacatalog/Population-ranking-table. Accessed on 22 January 2018.

World Bank. (2018 c) Country profile - Pakistan. World Development Indicators database. http://databank.worldbank.org/data/views/reports/reportwidget.aspx?Report_Name=Co untry Profile\& $I d=b 450 f d 57 \&$ tbar $=y \& d d=y \& i n f=n \& z m=n \&$ country=PAK

WRI (2019) What is degraded land? https://www.wri.org/faq/what-degraded-land 
WWF (2012) Annual Report - WWF-Pakistan's Yearly Progress Reports. Available at:

https://www.wwfpak.org/knowledge hub /annual report /

Yocco V (2015) Characteristics of an Innovation - an article published on 29 January 2015 in the "Smashing Magazine". Jan 2015.

Zubair M, Garforth C (2006) Farm level tree planting in Pakistan: the role of farmers' perceptions and attitudes. Agrofor Syst 66:217-229. 